Original article

\title{
Epidemiology of dermatophytoses in 31 municipalities of the province of Buenos Aires, Argentina: A 6-year study
}

\author{
Mariana Mazzaa,*, Nicolás Refojo ${ }^{a}$, Graciela Davel ${ }^{a}$, Nelson Lima ${ }^{a}$, \\ Nicolina Dias ${ }^{\mathrm{b}}$, Cosme Marcelo Furtado Passos da Silva ${ }^{\mathrm{c}}$, Cristina Elena Canteros ${ }^{\mathrm{a}}$, \\ Mycology Network of the Province of Buenos Aires (MNPBA) $)^{1}$ \\ a Mycology Department, INEI, ANLIS “Dr. Carlos G. Malbrán”, Ciudad Autónoma de Buenos Aires, Argentina \\ ${ }^{\mathrm{b}}$ CEB - Centre for Biological Engineering, Universidade do Minho, Campus de Gualtar, Braga, Portugal \\ ${ }^{\mathrm{c}}$ Department of Epidemiology and Quantitative Methods in Health, National School of Public Health - Oswaldo Cruz Foundation (FIOCRUZ), Rio de Janeiro, RJ, Brazil
}

\section{A R T I C L E I N F O}

\section{Article history:}

Received 14 October 2016

Accepted 27 July 2017

Available online 29 March 2018

\section{Keywords:}

Dermatophytosis

Epidemiology

Retrospective study

\begin{abstract}
A B S T R A C T
Background: No reliable data are available in the province of Buenos Aires regarding the frequency of dermatophytoses and other fungal diseases. The distribution of the clinical forms and the species involved are also unknown.

Aims: To present the data collected by the laboratories participating in the Mycology Network of the province of Buenos Aires (MNPBA) from a retrospective epidemiological survey on dermatophytoses. Methods: A descriptive and exploratory analysis was performed on the cases of dermatophytoses gathered between 2002 and 2007 by the Mycology Network of the province of Buenos Aires.

Results: Of the 3966 dermatophytosis cases reported by 41 laboratories in 31 municipalities, more than a half occurred in three highly populated urban municipalities. The male:female ratio was $1: 1.5$. The most frequent clinical form was tinea unguium, diagnosed in 904 cases $(51.83 \%)$, followed by tinea capitis (19.32\%), tinea corporis (15.19\%), tinea pedis (6.77\%), tinea cruris (3.73\%), and tinea manuum $(2.18 \%)$. The species involved was identified in 1368 (33.49\%) cases. Trichophyton rubrum was the most common species, with a frequency of $42.03 \%$. An association was found between urban municipalities and T. rubrum or the Trichophyton mentagrophytes complex.

Conclusions: Results from the MNPBA survey provide valuable information that should enable further interventions to be designed in order to prevent and control the disease.
\end{abstract}

@ 2017 Asociación Española de Micología. Published by Elsevier España, S.L.U. All rights reserved.

\section{Epidemiología de las dermatofitosis en 31 municipios de la provincia de Buenos Aires, Argentina: estudio de 6 años}

\section{R E S U M E N}

Antecedentes: No existen datos fiables acerca de la frecuencia de las dermatofitosis y otras enfermedades fúngicas en la provincia de Buenos Aires. Por otra parte, la distribución en la provincia de las formas clínicas y las especies involucradas no es conocida.

Objetivos: El objetivo de este estudio fue reportar los datos recogidos por los laboratorios que participan en la Red de Micología de la Provincia de Buenos Aires (MNPBA) a través del análisis de encuestas epidemiológicas retrospectivas sobre casos notificados de dermatofitosis.

\footnotetext{
* Corresponding author.

E-mail address: pnccm@anlis.gov.ar (M. Mazza).

1 Mycology Network of the Province of Buenos Aires (MNPBA). See Appendix A for a complete list of members.
} 
Métodos: Se realizó un análisis descriptivo y exploratorio de los casos de dermatofitosis recogidos por los laboratorios de la Red de Micología de la provincia de Buenos Aires durante un período de 6 años (2002-2007).

Resultados: Se registraron 3.966 casos procedentes de 41 laboratorios distribuidos en 31 municipios. Más de la mitad de los casos tuvieron lugar en tres municipios urbanos muy poblados. La proporción varón:mujer fue de 1:1,5. La forma clínica más frecuente fue tinea unguium, diagnosticada en 904 casos (51,83\%), seguida de tinea capitis (19,32\%), tinea corporis $(15,19 \%)$, tinea pedis $(6,77 \%)$, tinea cruris $(3,73 \%)$ y tinea manuum (2,18\%). La identificación de las especies de dermatofitos se realizó en 1.368 casos (33,49\%). La especie predominante fue Trichophyton rubrum (42,03\%). Se observó asociación entre los municipios de alta densidad poblacional y la presencia de T. rubrum y del complejo de especies Trichophyton mentagrophytes.

Conclusiones: Los resultados de las encuestas de MNPBA generan información de calidad que permite el diseño de nuevas intervenciones para la prevención y control de estas micosis.

(C) 2017 Asociación Española de Micología. Publicado por Elsevier España, S.L.U. Todos los derechos reservados.

In 1997 the Mycology Department of the National Institute of Infectious Diseases (INEI, ANLIS “Dr. Carlos G. Malbrán”, City of Buenos Aires, Argentina) established the National Mycology Laboratories Network ${ }^{6}$ whose main objectives are (1) to provide clinical diagnoses to the whole population, (2) to contribute to the control of the mycoses, (3) to participate in the surveillance of fungal infections and emerging fungal pathogens, (4) to enable staff to perform standardized laboratory procedures, and (5) to provide tools for improving the quality of the diagnoses. The National network comprises 130 laboratories grouped according to their complexity level and the step required to reach a diagnosis (Fig. 1). The laboratories are distributed in 23 provinces. If a laboratory fails to provide a conclusive diagnosis, the mycological sample must be sent to a laboratory of a higher level of complexity in the same province. In Argentina, the Clinical Mycology National Reference Laboratory (CMNRL) is the one with the highest complexity level in relation to tasks and diagnostic tools (level 4), where inconclusive mycological diagnoses from other laboratories are collected.

Dermatophytoses affect millions of people and are the most common fungal infections worldwide. Its incidence is rising and represents a public health concern with a significant impact on health-care costs. ${ }^{3,19}$ Although in most cases the infection remains in the stratum corneum of the epidermis and the outcome is mild, it can shift to a more severe condition depending on the patients' immune status. ${ }^{16,18}$ Therefore, dermatophytoses and their causative agents vary according to a wide range of factors (ethnic group, life-style, socio-economic conditions, geo-climatic factors, and geographical location). ${ }^{10}$ In Argentina reliable epidemiological data on dermatophytoses are lacking for the Province of Buenos Aires (PBA), which comprises 134 municipalities located on a $307,571 \mathrm{sq}$. $\mathrm{km}$ area. At present 55 laboratories from 31 municipalities participate in the Mycology Network of the PBA (MNPBA). Crowded suburbs around the capital city (Metropolitan Buenos Aires; 9,270,661 inhabitants), with industrial, and commercial activities and services, are included. The rest of the province is less densely populated, with 4,556,542 inhabitants involved in rural activities. ${ }^{11,12}$

The aim of the study was to report the data collected in a retrospective epidemiological survey on dermatophytoses. Data were collected by the laboratories of the MNPBA under the coordination of the Mycology Department of INEI, ANLIS “Dr. Carlos G. Malbrán”. Between 2002 and 2007 a descriptive and exploratory analysis of dermatophytoses was performed.

\section{Methods}

From January 2002 to December 2007 a six-year retrospective epidemiological review of 5650 cases of superficial mycoses was carried out. In order to collect the data, a form with closed questions was created and distributed to the laboratories. Records of dermatophytoses were collected monthly from 55 public clinical laboratories of the MNPBA, Argentina. The criteria for a clinical diagnosis of dermatophytosis were positive direct examination (hyaline septate hyphae, with or without arthroconidia) and/or dermatophyte-positive culture according to the criteria established by the CMNRL, the Mycology Department of the National Institute of Infectious Diseases ANLIS “Dr. Carlos G. Malbrán”. Demographic and clinical data were recorded, including patients' age, gender, etiologic agent and clinical form of the lesion, the laboratory identification, and sampling date. During 2005 and 2006 the etiologic agent was not recorded and for 2007 this information was only partially recorded. This study was approved by the Research Ethics Committee of National Institute of Epidemiology "Dr. Juan H. Jara”.

\section{Statistical analysis}

The population was stratified into seven groups according to patients' age (<9 years; $10-19 ; 20-29 ; 30-39 ; 40-49 ; 50-59$; >60 years). Pearson's Chi Square $\left(\chi^{2}\right)$ test was performed to study the relationship between the frequency of dermatophytosis and the selected variables, and to find significant differences in the distribution of each species. $P$-values $\leq 0.05$ were considered statistically significant using R Software, version 2.9 .2 (24/08/2009). ${ }^{23}$

In order to study the relationship between the etiologic agents and the population density the municipalities were categorized in two groups: (a) high population density districts ( $>500$ inhabitants/sq. $\mathrm{km}$ ) which were mainly urbanized and industrialized, and (b) low population density districts ( $\leq 500$ inhabitants/sq. km), mainly rural (agriculture and livestock). The relationship between dermatophytosis and population distribution over the geographical areas of 31 municipalities of the PBA was determined by the Kernel Method. The kernel estimator provided a continuous surface of densities calculated for all areas. ${ }^{4}$ The kernel parameters used in this study were the quadratic estimation function $(k)$ and bandwidth fixed at $1000 \mathrm{~m}$. TerraView software, version 3.2.0 (03/07/2008) was used for spatial analysis. Each municipality of the PBA was one unit. 
High complexity laboratory (level 3)

-Serological diagnosis of endemic mycoses (coccidioidomycosis, paracoccidioidomycosis, histoplasmosis) and chronic aspergillosis -Diagnosis of subcutaneous and endemic mycoses -Dimorphic fungal pathogens identification -Molds identification

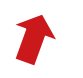

Intermediate complexity laboratory (level 2)

-Diagnosis of opportunistic mycoses

-Yeast identification

- Aspergillus section Nigri and

Aspergillus section Fumigati

identification
Low complexity laboratory (level 1)

-Diagnosis of superficial mycoses -Dermatophyte identification - Candida albicans identification -Diagnosis of oropharyngeal and vulvovaginal candidiasis

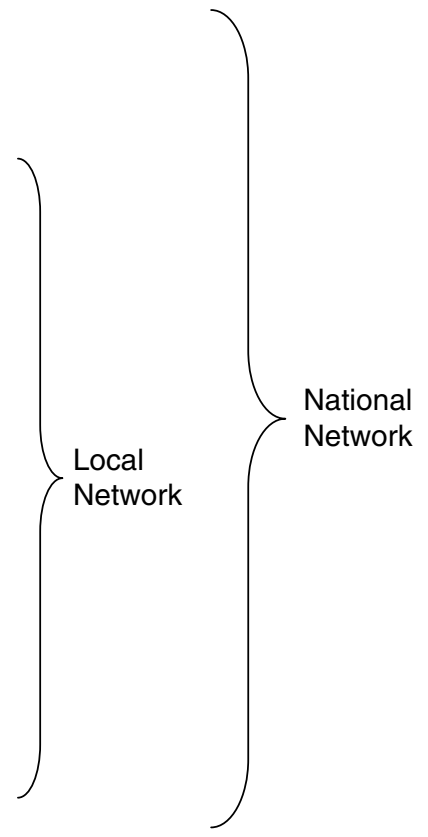

Fig. 1. Level of complexity of the laboratories and organizational structure of the Mycology Network.

\section{Results}

A total of 5650 cases of superficial mycoses were reported by $41(74.5 \%)$ of the 55 participating laboratories of the MNPBA. Of those, 3966 were dermatophytosis cases, and accounted $70.2 \%$ of all reported cases. However, it was not possible to confirm the definitive diagnosis through the culture in 333 cases, then only a presumptive diagnosis of dermatophytosis should be considered. Yeast infections accounted for 1678 (29.7\%) cases, and the remaining six cases were infections produced by opportunistic filamentous fungi. Of 3966 cases of dermatophytoses, clinical forms were recorded in 1744 (44\%) cases. Out of those, 1313 cases in which the etiologic agent was identified, were distributed in different clinical forms (Table 1 ), the most frequent one being tinea unguium, diagnosed in 671 cases (51.1\%), followed by tinea capitis and tinea corporis, reported in 269 (20.5\%) and 202 patients (15.4\%), respectively. Tinea pedis, tinea cruris and tinea manuum accounted for the remaining $11.9 \%$. In 15 cases (1.1\%), two clinical forms were simultaneously found.

The most frequently isolated species were Trichophyton rubrum (42.6\%), the Trichophyton mentagrophytes complex (23.9\%), and Microsporum canis (21.5\%). All the other genera and/or species were found at a rate below $10 \%$. A mixed infection of $T$. rubrum and the
T. mentagrophytes complex was found in one case. A Chi-square $\left(\chi^{2}\right)$ test revealed significant relationship $(P$-value $<0.0001$; data not shown) between the etiologic agent and the clinical form for the 1313 confirmed dermatophytoses cases found in the six-year study. The dermatophytes $T$. rubrum and the T. mentagrophytes complex were linked to tinea unguium, and M. canis with tinea capitis. Fig. 2 illustrates the distribution of dermatophytoses according to the patients' gender and age. Out of the 3966 cases of dermatophytoses, a total of 2271 cases $(57.2 \%)$ occurred in females, and $1601(40.3 \%)$ in males. The male to female ratio was $1: 1.5$. With respect to the clinical forms and gender, tinea unguium, tinea pedis, and tinea corporis were predominantly found in females, while tinea manuum, tinea capitis, and tinea cruris affected males more commonly. The distribution of dermatophytoses through the seven age-stratified groups revealed a high prevalence of tinea capitis and tinea corporis ( $88 \%$ ) in childhood (0-9 years of age). Concerning other clinical forms, tinea unguium was prevalent (63\%) in adult patients (20-59 years).

The clinical laboratories reporting dermatophytoses were distributed over 31 of $134(23.1 \%)$ municipalities in the PBA. Fourteen municipalities were characterized by a population density $>500$ inhabitants/sq. km, mainly urbanized and industrialized, and 17 had a population density $\leq 500$ inhabitants/sq. $\mathrm{km}$, being

Table 1

Number and percentage (in parenthesis) of identified species of dermatophytes according to the clinical form in a total of 1313 cases.

\begin{tabular}{|c|c|c|c|c|c|c|c|c|}
\hline \multicolumn{9}{|c|}{ Clinical form } \\
\hline Species & Tinea unguium & Tinea capitis & Tinea corporis & Tinea pedis & Tinea cruris & Tinea manuum & $\begin{array}{l}\text { Two different } \\
\text { clinical forms }\end{array}$ & Total (\%) \\
\hline Trichophyton rubrum & 388 & 6 & 81 & 48 & 20 & 9 & 8 & $560(42.6 \%)$ \\
\hline Trichophyton mentagrophytes complex & 196 & 24 & 46 & 19 & 13 & 14 & 2 & $314(23.9 \%)$ \\
\hline Microsporum canis & 5 & 219 & 41 & 1 & 14 & & 2 & $282(21.5 \%)$ \\
\hline Trichophyton spp. & 62 & 2 & 11 & 5 & & 2 & 2 & $84(6.4 \%)$ \\
\hline Trichophyton tonsurans & 11 & 6 & 6 & 1 & 2 & 1 & & $27(2.1 \%)$ \\
\hline Microsporum gypseum & 3 & 12 & 9 & & 1 & & & $25(1.9 \%)$ \\
\hline Epidermophyton floccosum & 4 & & 6 & 3 & 3 & & & $16(1.2 \%)$ \\
\hline Trichophyton verrucosum & 2 & & 2 & & & & & $4(0.3 \%)$ \\
\hline T. rubrum and T. mentagrophytes complex & & & & & & & 1 & $1(0.1 \%)$ \\
\hline Total & $671(51.1 \%)$ & $269(20.5 \%)$ & $202(15.4 \%)$ & $77(5.9 \%)$ & $53(4.0 \%)$ & $26(2.0 \%)$ & $15(1.1 \%)$ & 1313 \\
\hline
\end{tabular}

Pearson's Chi-square test $\chi^{2}=106.7003, \mathrm{GL}=10, P$-value $<2.2 \mathrm{e}^{-16}$. 
Tinea unguium

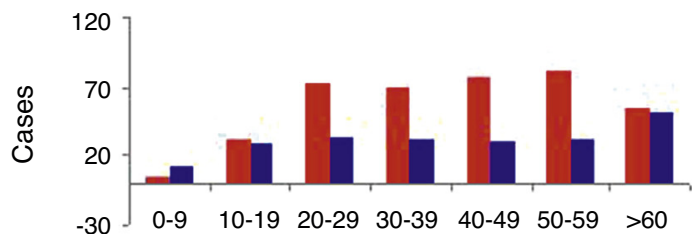

Age groups

Tinea corporis

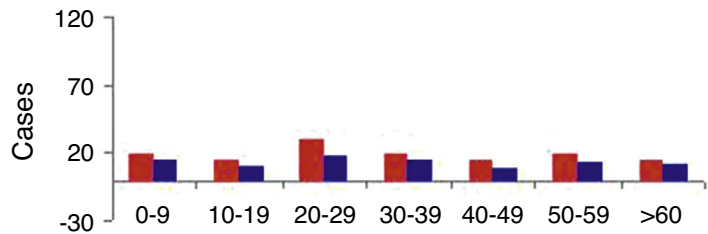

Age groups

Tinea cruris

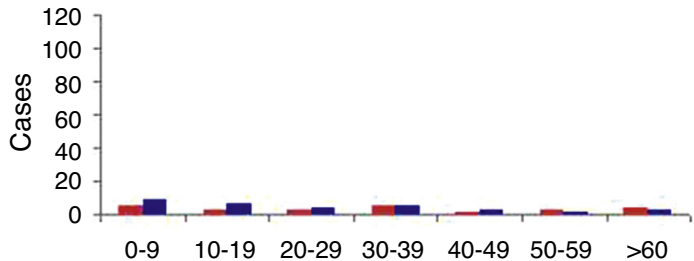

Age groups
Tinea capitis

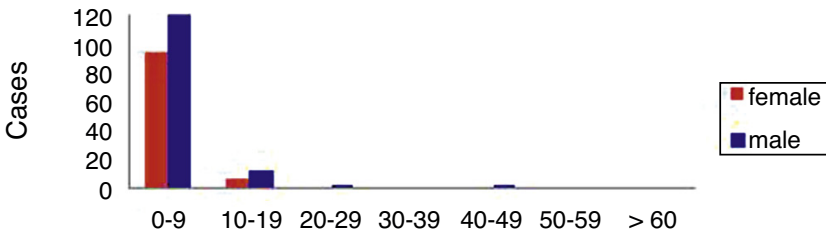

Age groups

Tinea pedis

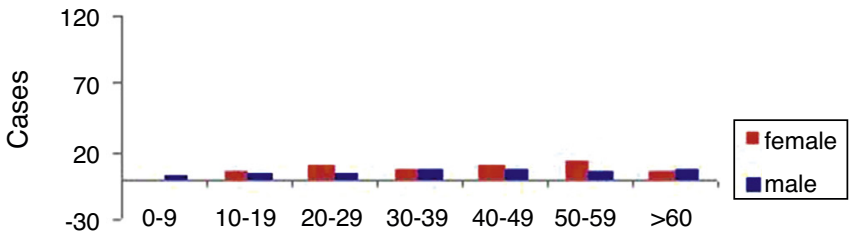

Age groups

Tinea manuum

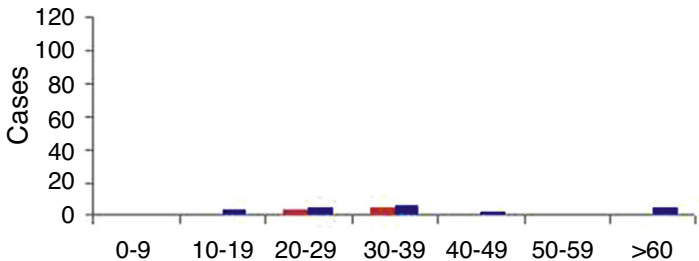

All dermatophytoses

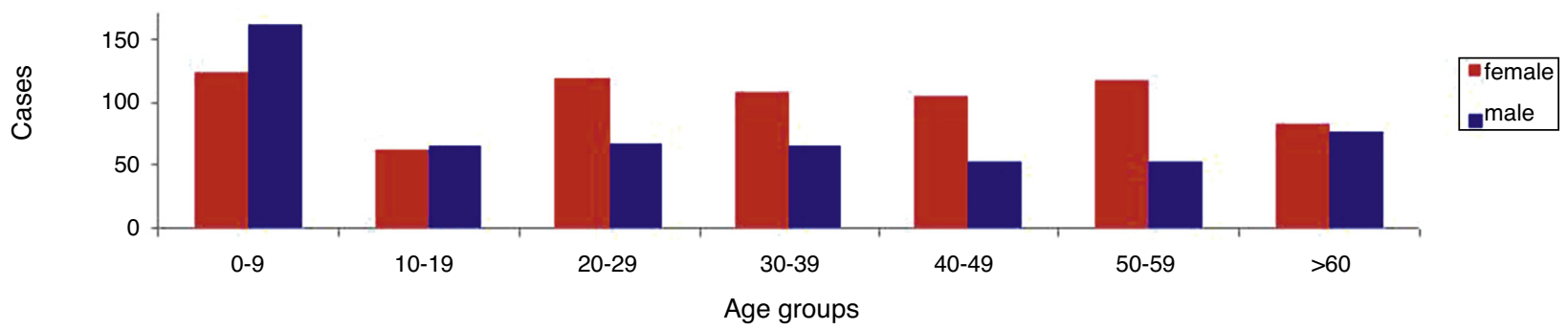

Fig. 2. Distribution of dermatophytosis according to the patient gender and age group.

Table 2

Dermatophytoses reported in the province of Buenos Aires, according to population density and year.

\begin{tabular}{|c|c|c|c|c|c|c|c|c|}
\hline \multirow[t]{2}{*}{ Population density } & \multirow{2}{*}{$\begin{array}{l}\text { Number of } \\
\text { municipalities }\end{array}$} & \multicolumn{6}{|c|}{ Number of cases per year } & \multirow{2}{*}{$\begin{array}{l}\text { Total cases } \\
\text { 2002-2007 }\end{array}$} \\
\hline & & 2002 & 2003 & 2004 & 2005 & 2006 & 2007 & \\
\hline Municipalities with >500 inhabitants/sq. km. & 14 & 293 & 424 & 314 & 860 & 384 & 770 & $3045(76.8 \%)$ \\
\hline Municipalities with $\leq 500$ inhabitants/sq. km. & 17 & 287 & 193 & 66 & 105 & 149 & 121 & $921(23.2 \%)$ \\
\hline Total & 31 & $580(15 \%)$ & $617(16 \%)$ & $380(10 \%)$ & $965(24 \%)$ & $533(13 \%)$ & $891(22 \%)$ & 3966 \\
\hline
\end{tabular}

predominantly rural municipalities (Table 2). The overall distribution of reported dermatophytoses cases varied from a minimum of 380 (10\%) cases/year in 2004 to 965 (24\%) cases/year in 2005. The high density municipalities accounted for $77 \%$ of the cases, and 2335 cases were reported in three of the 14 urbanized municipalities. Additionally, a high number of cases were reported in two rural municipalities (Junín and Olavarría) in 2002 (Fig. 3). The statistical analysis of the relationship between etiologic agents and population density showed significant differences $(P<0.0001)$. The dermatophytes T. rubrum and the T. mentagrophytes complex were 


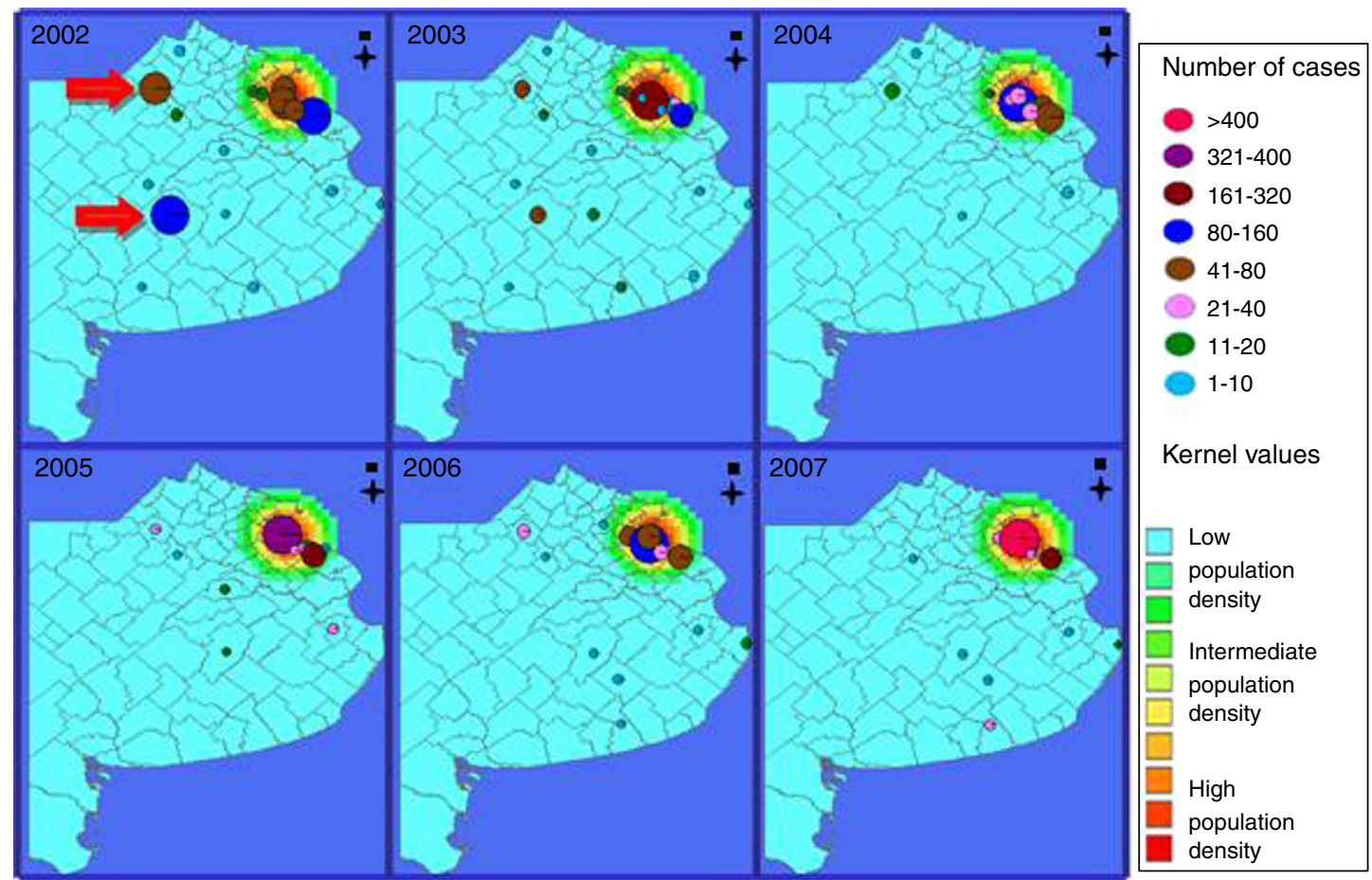

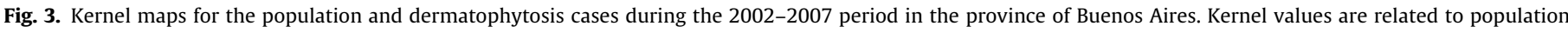

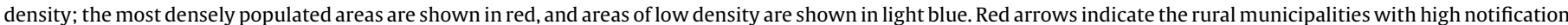
of dermatophytosis.

Table 3

Number of dermatophytes identified according to the population density of the municipalities of the province of Buenos Aires.

\begin{tabular}{lcc}
\hline Etiologic agents & \multicolumn{2}{c}{ Population density } \\
\cline { 2 - 3 } & $\begin{array}{c}>500 \text { inhabitants/sq. } \\
\mathrm{km}\end{array}$ & $\begin{array}{c}\leq 500 \text { inhabitan } \\
\mathrm{km}\end{array}$ \\
\hline Trichophyton rubrum & 409 & 166 \\
Trichophyton mentagrophytes & 231 & 85 \\
$\quad$ complex & 108 & 176 \\
Microsporum canis & 61 & 52 \\
Trichophyton spp. & 10 & 16 \\
Microsporum gypseum & 9 & 18 \\
Trichophyton tonsurans & 1 & 16 \\
Epidermophyton floccosum & 1 & 4 \\
Trichophyton verrucosum & 1 & 0 \\
Trichophyton rubrum and $T$. & 0 & 4 \\
$\quad$ mentagrophytes complex & & \\
Microsporum spp. & &
\end{tabular}

Pearson' Chi-square test $\chi^{2}=106.7003, \mathrm{GL}=10, P$-value $<2.2 \mathrm{e}^{-16}$.

linked to urban municipalities, and $M$. canis to rural areas (Table 3). The data were calculated on the basis of 1368 cases confirmed by fungal culture.

\section{Discussion}

The results show that from 2002 to 2007 dermatophytosis was the most common superficial mycosis in the PBA. There were more female cases, which agrees with previous studies performed in different regions of Argentina. ${ }^{6,7,17}$ In contrast, other studies conducted in Portugal ${ }^{8,20}$ and Mexico ${ }^{14}$ showed no significant gender differences, and Chinelli et al. ${ }^{5}$ reported a higher frequency of dermatophytoses in males in Brazil. It is likely that in this study women attended the dermatology service more often than men for some reasons, including the esthetic one, which possibly resulted in a bias. A cohort study should be undertaken to confirm this potential association.
Dermatophytoses are mostly concentrated in geographic areas with higher population density in PBA. Kernel maps clearly showed a concentration of cases in densely populated areas, which correlated with the two most frequent species (T. rubrum and the $T$. mentagrophytes complex) predominant in those areas. T. rubrum was the most frequently isolated species, probably due to its regular presence in dermatophytosis in large urban centers. The reason might be the number of people attending public swimming pools, gyms, and other sports facilities, known sources of infection by anthropophilic species as T. rubrum. 9,10

Different fungal species were correlated to different types of tineas. In the current study, tinea unguium was the most frequent clinical form reported, the prevalent etiologic agent being the anthropophilic dermatophyte T. rubrum. Other partial studies in Argentina ${ }^{7,17}$ and several retrospective surveys from different parts of the world $9,13,14,15,20,21$ confirmed the progressive increase of tinea unguium, which has reached its highest overall frequency, and the predominance of $T$. rubrum as an etiologic agent; occlusive footwear has been pointed out as a key factor. $9,19,21$ The zoophilic species $M$. canis has been reported as the agent more frequently involved in cases of tinea corporis and tinea capitis. ${ }^{2,22}$ A heterogeneous distribution of the frequencies of the species, probably due to factors related to the geographical area and/or environmental conditions, might explain the differences found in the study by Abastabar et al. ${ }^{1}$

In this study the scant notification in most municipalities in the PBA (31 of 134 municipalities) allowed to only draw an estimate of the real situation. To overcome this, more clinical laboratories should be enrolled in the MNPBA and encouraged to report epidemiological data through the National Health Surveillance System. Notification forms proved to be a useful tool even if minor modifications are still needed. Other study designs allow to determine the incidence of diseases and risk factors but involve high costs, which is not ideal when studying a non life-threatening disease. This retrospective, economic and cross-sectional survey conducted 
in the MNPBA laboratories appears to be appropriate since it allows implementing measures to control and prevent further transmission of the disease.

\section{Conflict of interests}

The authors declare that they have no conflict of interests.

\section{Acknowledgement}

The authors would like to thank Verónica Trevisán for collecting the data.

\section{Appendix A.}

Hermida AM, Hospital Interzonal General "Dr. Lucio Meléndez" Mariñansky AL, Hospital Zonal General de Agudos “Dr. Arturo Oñativia"

Lanzetta D, Hospital Interzonal General de Agudos "Presidente Perón"

Sarandón RE, Hospital Materno Infantil "A. Diego"

Schiaffino MA, Hospital Municipal Base de Azul "Dr. Angel Pintos"

Moretti M, Hospital Interzonal General de Agudos "Evita Pueblo"

Roschich N, Hospital Zonal General de Agudos "Dr. Mario Larraín"

Jofré ME, Hospital Miguel Capredoni

Alfonso LI, Hospital Municipal "San Luis"

Urquijo L, Hospital Municipal "Manuel B. Cabrera"

D'Angelo C - Pasquetti E, Unidad Sanitaria "San Roque"

Pestana L, Hospital Zonal General de Agudos "Horacio Cestino"

Pereyra R, Hospital Zonal "Madre Teresa de Calcuta"

Delaplace L, Hospital Municipal "Mi Pueblo"

Fanjul V, Hospital Interzonal Especializado Materno Infantil "Don Victorio Tetamanti"

Gullo H, Hospital Zonal General de Agudos "Vicente López y Planes"

\section{Casanova NB, CRAI-Norte CUCAIBA}

Tuduri A, Hospital Interzonal General de Agudos "Eva Perón”

Albera AR, Hospital Municipal “Dr. Diego Thompson"

Machain M, Hospital Zonal de Agudos de Junín "A. Piñeyro"

De Magistris M, Hospital Municipal "León Dios"

Mónaco LS, Hospital Zonal General de Agudos “Dr. Diego Paroissien"

Featherston PL, Hospital Interzonal de Agudos y Crónicos "San Juan de Dios"

Turcato G, Hospital Interzonal Especializado de Agudos "Sor María Ludovica"

Sallaber S, Hospital Interzonal General de Agudos "Prof. Dr. Rodolfo Rossi"

Russo G, Hospital Zonal "Nuestra Señora de Luján"

López Camelo W, Hospital Zonal Especializado "Dr. Cabred"

Cuevas F, Hospital Materno Infantil de Pontevedra

Posse GB, Hospital Provincial "Héroes de Malvinas"

Traverso S, Hospital Interzonal General de Agudos "Dr. Luis Güemes"

Capece P, Hospital Nacional "Dr. Alejandro Posadas"
Giampaoli LF, Hospital Municipal "Dr. Emilio Ferreyra”

Psenda L, Hospital Municipal “Dr. Héctor Cura”

Gagliardi S, Hospital Interzonal General de Agudos "San José”

Vallespi G, Hospital Zonal General de Agudos "Dra.Cecilia Grierson"

Herrera J0, Hospital Zonal General de Agudos “Dr. Isidoro Iriarte"

Ginzo MI, Hospital Zonal General "Dr. A. Posadas"

Gallo D, Hospital Municipal de Giles

Sparo M, Hospital Municipal "Ramón Santamarina"

Fernández CN, Hospital Zonal Especializado de Agudos y Crónicos "Dr. A. Cetrángolo"

\section{References}

1. Abastabar M, Rezaei-Matehkolaei A, Shidfar MR, Kordbacheh P, Mohammadi R, Shokoohi T, et al. A molecular epidemiological survey of clinically important dermatophytes in Iran based on specific RFLP profiles of beta-tubulin gene. Iran J Public Health. 2013;42:1049-57.

2. Arenas R. Dermatofitosis en México. Rev Iberoam Micol. 2002;19:63-7.

3. Bhadauria S, Kumar P. Broad spectrum antidermatophytic drug for the control of tinea infection in human beings. Mycoses. 2012;55:339-43.

4. Carvalho MS, Souza-Santos R. Análise de dados espaciais em saúde pública: métodos, problemas, perspectivas. Cad Saude Publica. 2005;21:361-78.

5. Chinelli PA, Sofiatti Ade A, Nunes RS, Martins JE. Dermatophyte agents in the city of Sao Paulo, from 1992 to 2002. Rev Inst Med Trop Sao Paulo. 2003;45:259-63.

6. Davel G, Canteros CE. Situación de las micosis en la República Argentina. Rev Argent Microbiol. 2007;39:28-33.

7. Davel G, Perrotta D, Canteros C, Cordoba S, Rodero L, Brudny M, et al. Estudio multicéntrico de micosis superficiales en Argentina. Rev Argent Microbiol 1999;31:173-81.

8. Dias N, Santos C, Portela M, Lima N. Toenail onychomycosis in a Portuguese geriatric population. Mycopathologia. 2011;172:55-61.

9. Drakensjo IT, Chryssanthou E. Epidemiology of dermatophyte infections in Stockholm Sweden: a retrospective study from 2005-2009. Med Mycol. 2011;49:484-8

10. Havlickova B, Czaika VA, Friedrich M. Epidemiological trends in skin mycoses worldwide. Mycoses. 2008;51 Suppl. 4:2-15.

11. Instituto Geográfico Nacional. Available from: http://www.ign.gob.ar [accessed 16.05.09].

12. Instituto Nacional de Estadísticas y Censos. Available from: http://www.indec.gov.ar [accessed 09.03.09].

13. Jankowska-Konsur A, Dylag M, Hryncewicz-Gwozdz A, Plomer-Niezgoda E Szepietowski JC. A 5-year survey of dermatomycoses in southwest Poland, years 2003-2007. Mycoses. 2011;54:162-7.

14. Lopez-Martinez R, Manzano-Gayosso P, Hernandez-Hernandez F, Bazan-Mora E Mendez-Tovar LJ. Dynamics of dermatophytosis frequency in Mexico: an analysis of 2084 cases. Med Mycol. 2010;48:476-9.

15. Maraki S, Nioti E, Mantadakis E, Tselentis Y. A 7-year survey of dermatophytoses in Crete Greece. Mycoses. 2007;50:481-4.

16. Marconi VC, Kradin R, Marty FM, Hospenthal DR, Kotton CN. Disseminated dermatophytosis in a patient with hereditary hemochromatosis and hepatic cirrhosis: case report and review of the literature. Med Mycol. 2010;48:518-27.

17. Nardin ME, Pelegri DG, Manias VG, Mendez Ede L. Agentes etiológicos de micosis superficiales aislados en un Hospital de Santa Fe Argentina. Rev Argent Microbiol. 2006:38:25-7.

18. Rodwell GE, Bayles CL, Towersey L, Aly R. The prevalence of dermatophyte infection in patients infected with human immunodeficiency virus. Int J Dermatol. 2008:47:339-43.

19. Seebacher C, Bouchara JP, Mignon B. Updates on the epidemiology of dermatophyte infections. Mycopathologia. 2008;166:335-52.

20. Valdigem GL, Pereira T, Macedo C, Duarte ML, Oliveira P, Ludovico P, et al. A twenty-year survey of dermatophytoses in Braga, Portugal. Int J Dermatol. 2006;45:822-7.

21. Vena GA, Chieco P, Posa F, Garofalo A, Bosco A, Cassano N. Epidemiology of dermatophytoses: retrospective analysis from 2005 to 2010 and comparison with previous data from 1975. New Microbiol. 2012;35:207-13.

22. Welsh O, Welsh E, Ocampo-Candiani J, Gomez M, Vera-Cabrera L. Dermatophytoses in Monterrey México. Mycoses. 2006;49:119-23.

23. R Development Core Team (2008). R: A language and environment for statistical computing. R Foundation for Statistical Computing, Vienna, Austria. ISBN 3-900051-07-0, http://www.r-project.org. 